\title{
New data on Marthiella Buffington (Hymenoptera, Cynipoidea, Figitidae), with description of a new species
}

\author{
Fabiana E. Gallardo ${ }^{1,2}$, Vanina A. Reche ${ }^{1}$, \& Ricardo Ferreira Monteiro 3
}

\begin{abstract}
${ }^{1}$ División Entomología, Facultad de Ciencias Naturales y Museo. Universidad Nacional de La Plata, Paseo del Bosque s/n, 1900 La Plata, Buenos Aires, Argentina. gallardo@fcnym.unlp.edu.ar; vaninaareche@yahoo.com.ar

${ }^{2}$ Researcher of the "Comisión de Investigaciones Científicas de la provincia de Buenos Aires" (CIC)

${ }^{3}$ Laboratório de Ecologia de Insetos, Departamento de Ecologia, Instituto de Biologia, Universidade Federal do Rio de Janeiro, Caixa postal 68020 , 21941-590, Rio de Janeiro-RJ, Brasil.monteiro@biologia.ufrj.br
\end{abstract}

\begin{abstract}
New data on Marthiella Buffington (Hymenoptera, Cynipoidea, Figitidae), with description of a new species. A new species of Marthiella Buffington (Hymenoptera, Figitidae) from Brazil and Nicaragua is described and illustrated. Rhabdeucoela semirufa Kieffer is transferred to Marthiella and a new combination was established: Marthiella semirufa. A key for identifying species of Marthiella is provided in this study.
\end{abstract}

KEYWORDS. Agromyzidae; Diptera; host records; Insecta; parasitoids; taxonomy.

Eucoilinae, a subfamily of Figitidae, are the most speciesrich group of figitids. This group includes most neotropical species of figitids, some of which are included in the tribe Zaeucoilini, bringing together 13 genera and approximately 40 species. Eucoilinae are endoparasitoid koinobionts of Diptera Muscomorpha in the families Lonchaeidae, Tephritidae, Drosophilidae, Otitidae (dipterous frugivorous), and Agromyzidae (dipterous miners). Species of Marthiella Buffington belong to Zaeucoilini, and their representatives were reared from agromyzid flies of Haplopeodes Steyskal and Calycomyza Hendel (Buffington 2009).

Aegeseucoela was proposed by Buffington (2002) as a new name for Moneucoela Dalla Torre \& Kieffer, 1910. The name Moneucoela is a junior homonym of Moneucoela Dalla Torre \& Kieffer, 1907 (in Kieffer 1907). Aegeseucoela included two species, A. flavotincta (Kieffer, 1908) and $A$. grenadensis (Ashmead, 1900), as it was defined by Buffington (2002), but was later determined to not be monophyletic (Buffington et al. 2007). Therefore, Buffington (2009) transferred the type species A. grenadensis to the genus Agrostocynips Díaz, and proposed Marthiella to accommodate $A$. flavotincta. In this study, we describe a new species of Marthiella and transfer Rhabdeucoela semirufa Kieffer, 1907, to Marthiella.

\section{MATERIAL AND METHODS}

We studied a total of 27 specimens, belonging to the following institutions: California Academy of Sciences (CAS), USA; Museu Nacional da Universidade Federal do Rio de Janeiro (MNRJ), Brazil; and Museo de La Plata (MLP), Argentina. The studied specimens were directly compared with type specimens of Marthiella flavotincta. The terminology used in the descriptions follows Buffington (2009). The measurements reported are relative, except for total length (head to abdominal tip without antennae), antennae length, and forewing length, which are expressed in millimeters $(\mathrm{mm})$. The distributions follow the biogeographical scheme of Cabrera \& Willink (1980). The illustrations were done with a camera lucida attached to a stereo microscope (Wild Heerbrugg M5A).

\section{TAXONOMY}

\section{Marthiella Buffington, 2009}

\section{Marthiella Buffington, 2009: 176. Type species: Rhabdeucoela flavotincta Kieffer, 1908.}

Diagnosis. Marthiella species can be recognized by the following combination of characters: orbital furrows originating at the lateral side of ocellus; genal carina well developed; medial mesoscutal keel present; dorsal surface of scutellum reticulate; laterodorsal projections of scutellum present and posterior projections absent; forewing hyaline, dusky at base, and marginal cell of forewing open, as long as deep.

Distribution (Fig. 1). USA, Mexico, Belize, Guatemala, Costa Rica, Panama, and Bolivia (Kieffer 1907; Buffington 2002, 2009). New records from Nicaragua and Brazil. This distribution belongs to the southern Nearctic region and Neotropical region in the biogeographic provinces of Pacifica, Mesoamerican Mountain, Cerrado, and Atlantica (Amazonico Domain) sensu Cabrera \& Willink (1980).

Biology. Parasitoids of Diptera Agromyzidae (Buffington 2002). 
Marthiella nigra Gallardo sp. nov.

Figs. 2-9

Diagnosis. This species can be separated from other species in the genus by the following combination of characters: head and mesosoma black; orbital furrows straight, accompanying the interior margin of the eye; genal carina striate; mesoscutellum straight posteriorly.

Description. Female. Total length 1.30-1.70 mm. Head and mesosoma black; metasoma dark brown; antennae, mandibles and legs yellowish brown, coxae darkened; forewing veins brown. Orbital furrows present (Fig. 2), originating at lateral side of the ocellus, straight, lining the interior margin of the eye, terminating at the malar sulcus. Malar space smooth with conical protuberances. Malar sulcus simple. Antennae (Fig. 3) stout, total length 1.30-1.40 mm, relative length of antennal articles $2: 1: 3: 2.5: 2: 2: 2.5: 2.5: 2: 2: 2: 2: 2.5$. Genal carina (Fig. 7) present, striate. Mesosoma (Fig. 7) stout. Pronotal plate (Fig. 4) wide, posterior half with a row of setae, lateral foveae open; dorsal margin of pronotal plate crested and bifurcate, with three emarginations. Sides of pronotum convex with a pubescent area on the upper half of the ventral margin (beneath pronotal plate). Mesoscutum (Figs. 5, 7) convex in profile. Medial mesoscutal keel (Fig. 5) prominent, continuous across entire mesoscutum with a constriction in the medial part, parapsidal ridges absent with scarce parapsidal hair line. Width-length ratio of mesoscutum in dorsal view 13:9.5; width-length of scutellar plate 4:7; width of scutellar plate-width of scutellum 4:7. Dorsal surface of scutellum (Fig. 6) areolate, margined laterally, straight posteriorly, laterodorsal projections present, and posterior projections absent. Scutellar plate (Fig. 6) large, suboval, posterior margin rounded, dorsal surface with tubercles, midpit placed centrally on plate. Metacoxa (Fig. 8) with band of setae along posterior margin. Forewings (Fig. 9) hyaline, dusky at base, apical margin with hair fringe; marginal cell open anteriorly. Total length of forewings $1.15-1.30 \mathrm{~mm}$, width-length relationship of marginal cell 4:6.5. Lateral propodeal carinae without protuberances. Metasoma (Fig. 7) sessile; distally smooth, micropunctures absent; hairy ring at base of syntergum complete, remainder of metasoma glabrous.

Male. Similar to female. Total length $1.30-1.70 \mathrm{~mm}$. Antennae yellowish brown, total length $1.70 \mathrm{~mm}$, relative length of antennal articles $2: 1: 3: 2.5: 2: 2: 2.5: 2.5: 2.5: 2: 2: 2$ : $2: 2: 2.5$. Total length of forewings $1.65 \mathrm{~mm}$. Hairy ring at base of syntergum interrupted dorsally.

Distribution (Fig. 1). Nicaragua and Brazil.

Type material. BRAZIL. Rio de Janeiro. Silva Jardim, Reserva

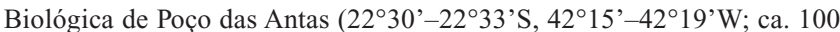
$\mathrm{m}$ altitude). Holotype female, 3 paratype males, reared from Calycomyza servilis Spencer (Agromyzidae) on Eupatorium odoratum L. (Asteraceae), 1998; 3 paratype females, reared from Calycomyza sp. 2 on Baccharis trinervis (Lam.) (Asteraceae), 1998, Barbosa da Silva coll. (MNRJ); 1 paratype female and 1 paratype male, reared from Calycomyza sp. 2 on Baccharis trinervis, 29/4/97; 2 paratype females, reared from Calycomyza

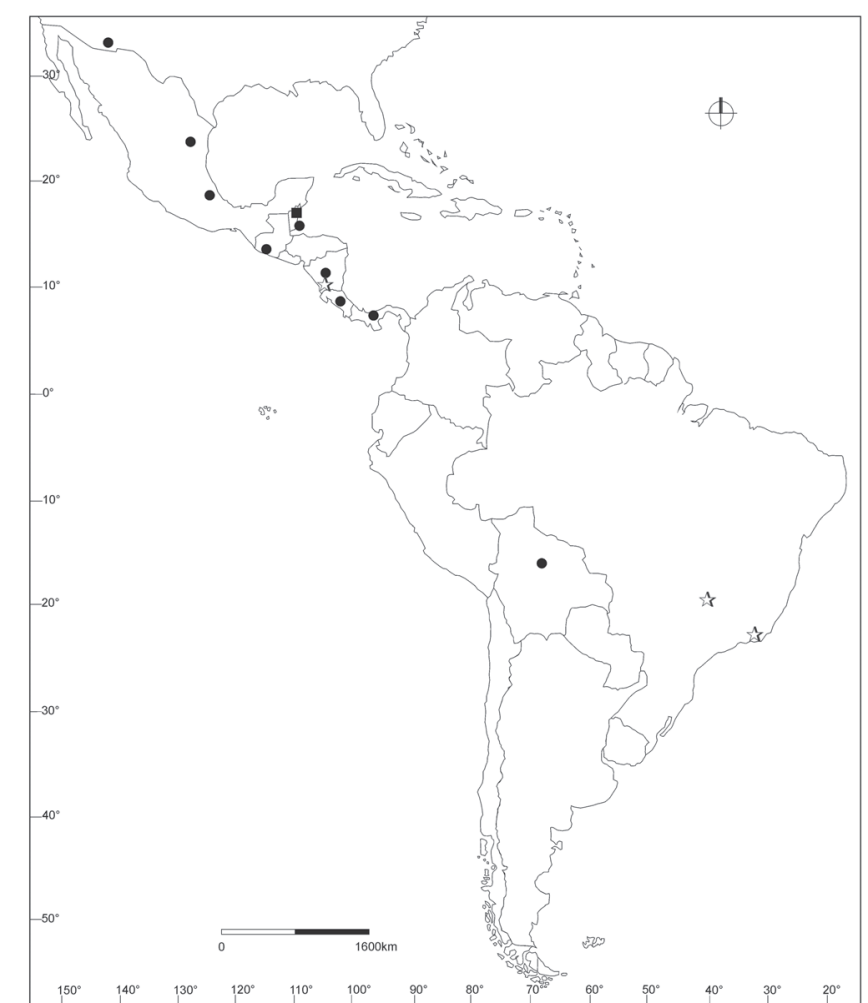

Fig. 1. Distribution of species of Marthiella. Symbols indicate locality records. (•) Marthiella flavotincta, (*) Marthiella nigra, (口) Marthiella semirufa.

sp. 1 on Vernonanthura beyrichii (Less.) (Asteraceae), 29/7/97; 2 paratype females reared from Calycomyza sp. 1 on Vernonanthura beyrichii, 23/1/ 98; 10 paratype females, reared from Calycomyza sp. 2 on Baccharis trinervis, 1998; 1 paratype female and 1 paratype male reared from Calycomyza eupatorivora Spencer on Eupatorium inulaefolium Kunth, 4/ 3/1998, Barbosa da Silva coll. Goiás. 1 paratype female, 19-II-1996, Marchiori coll., NICARAGUA. Granada. Volcán Mombacho, 1 paratype female, 30-VI-1998, Maes coll. (Malaise trap.) (MLP).

Etymology. The specific name refers to general body coloration.

Biology. Specimens of this new species were reared from Calycomyza sp. 1 on Vernonanthura beyrichii (Less.) H. Rob. with parasitism of $10 \%(\mathrm{n}=106$ mines $)$ and on Baccharis serrulata (Lam.) with parasitism of $18 \%(\mathrm{n}=22$ mines); reared from Calycomyza sp. 2 on B. trinervis (Lam.) with parasitism of $38 \%$ ( $\mathrm{n}=43$ mines); reared from C. servilis Spencer on Eupatorium odoratum L. with parasitism of $31 \%$ (n $=26$ mines); reared from $C$. eupatorivora on $E$. inulaefolium Kunth with parasitism of $11 \%(\mathrm{n}=88$ mines). All mines are expanded.

\section{Marthiella semirufa (Kieffer, 1907) comb. nov.}

Rhabdeucoela semirufa Kieffer, 1907: 71

Distribution (Fig. 1). Belize (Kieffer 1907).

Hosts. Unknown.

Type material. BELIZE. Holotype male, without further data (CAS 10605). 


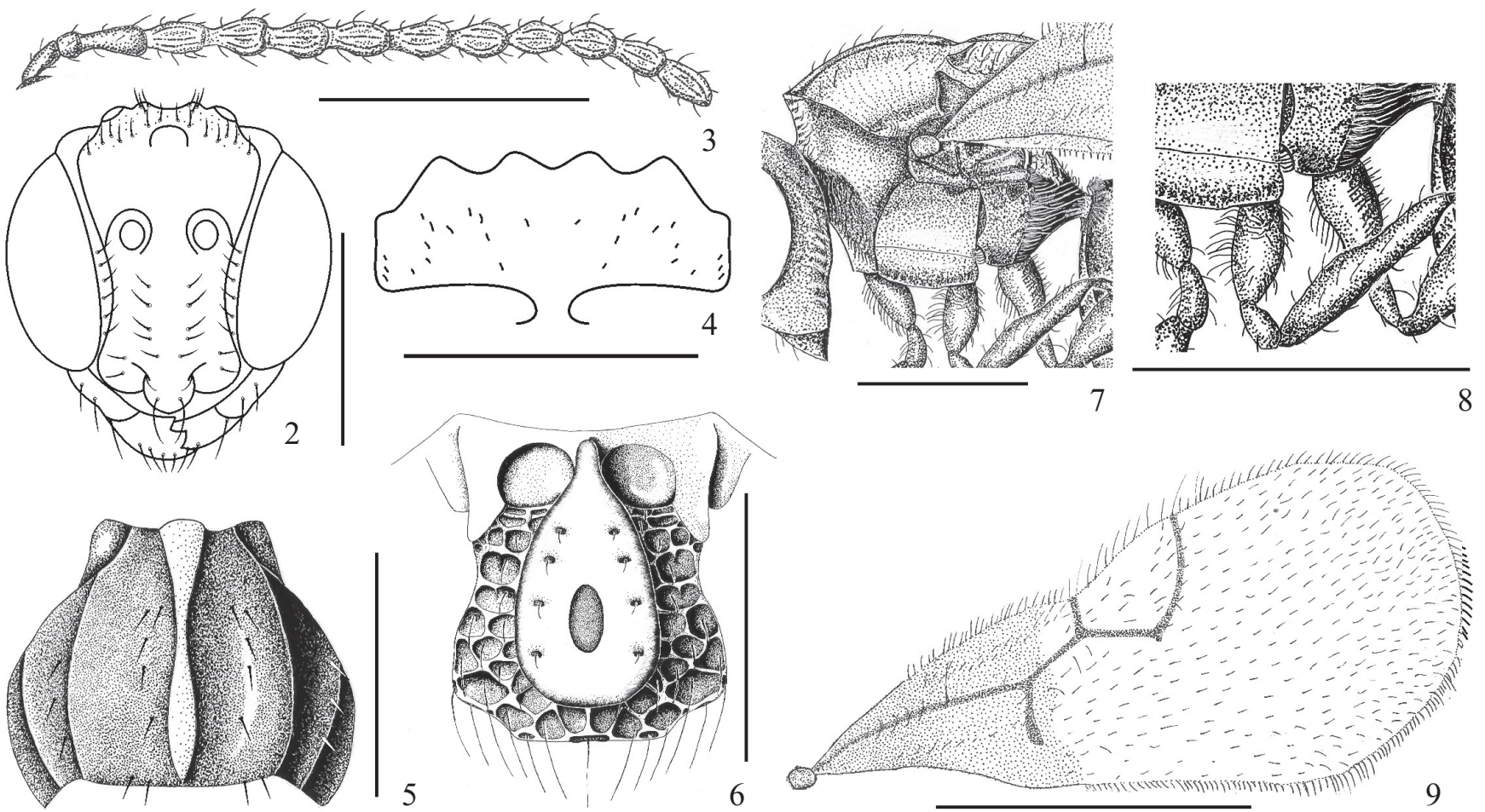

Figs. 2-9. Marthiella nigra Gallardo sp. nov., female. 2. Head, frontal view. 3. Antenna. 4. Posterior half of pronotal plate. 5. Mesoscutum, dorsal view. 6. Scutellum, dorsal view. 7. Mesosoma and base of metasoma, lateral view. 8. Detail of the legs. 9. Forewing. Scales: Figs. 2, 4-6: 0.50 mm; Fig. 3: 2 mm; Figs. 7-9: $1 \mathrm{~mm}$.

Remarks. After studying this species, we concluded that $R$. semirufa should be assigned to the genus Marthiella based on the following combination of characters: body stout; genal carina well developed, flanged posterior to compound eye; dorsal margin of pronotal plate crested and bifurcate; laterodorsal projections of mesoscutellum present and posterior projections absent; scutellar plate large, dorsal surface with setiferous tubercles to the sides of glandular pit.

\section{Key to species of Marthiella}

1. Head black, mesosoma reddish brown. Medial mesoscutal keel prominent and widened in anterior part. Dorsal surface of scutellum broadly areolate

M. semirufa (Kieffer)

1'. Head and mesosoma reddish brown or black. Medial mesoscutal keel prominent, with a constriction in the medial part (Fig. 5). Dorsal surface of scutellum finely areolate (Fig. 6)

\section{2}

2. Head and mesosoma black. Genal carina striate (Fig. 7). Orbital furrows straight. Dorsal surface of scutellum straight posteriorly (Fig. 6) .... M. nigra Gallardo sp. nov.

2'. Head and mesosoma reddish brown. Genal carina undulating (see Fig. 1A in Buffington 2002). Orbital furrows sinuous (see Fig. 1B in Buffington 2002). Dorsal surface of scutellum margined posteriorly .... M. flavotincta (Kieffer)

\section{ACKNOWLEDGMENTS}

The authors thank M. Buffington and an anonymous reviewer for the critical review of the manuscript. We thank R. Zuparko (CAS) for lending us the type material; J. J. Maes (SEAL), C. Marchiori, and R. F. Monteiro (UFRJ) for donating material to the collection of the Museo de La Plata; Cecilia Gorretta (CIC) and Julia Rouaux for technical support and Marcio Barbosa da Silva for assistance with fieldwork. This study was supported by Comisión de Investigaciones Cientificas de la Provincia de Buenos Aires (CIC) and Universidad Nacional de La Plata (UNLP), Argentina. We also thank CNPq (scholarship to RFM), INCT HYMPAR Sudeste (CAPES, FAPESP, CNPq) for financial support, ICMBio, and particularly the staff of the Biological Reserve of Poço das Antas (RJ, Brasil) for the licence and facilities to research in this protected area.

\section{REFERENCES}

Ashmead, W.H. 1900. Report upon the Aculeate Hymenoptera of the Islands of St. Vincent and Grenada, with additions to the parasitic Hymenoptera and a list of the described Hymenoptera of the West Indies. Transactions of the Entomological Society of London 1900: 207-367.

Buffington, M.L. 2002. Description of Aegeseucoela Buffington, new name, with notes on the status of Gronotoma Förster (Hymenoptera: Figitidae: Eucoilinae). Proceedings of the Entomological Society of Washington 104: 589-601.

Buffington, M.L. 2009. Description, circumscription and phylogenetics of the new tribe Zaeucoilini (Hymenoptera: Figitidae: Eucoilinae), 
including a description of a new genus. Systematic Entomology 34: $162-187$.

Buffington, M.L., Nylander, J.A.A. \& Heraty, J.M. 2007. The phylogeny and evolution of Figitidae (Hymenoptera: Cynipoidea). Cladistics 23: 403-431. Cabrera, A.L. \& Willink, A. 1980. Biogeografia de América Latina. Monografía Nro. 13, serie Biología. OEA, Washington. 122 p.
Dalla Torre, K. \& Kieffer, J. 1910. Cynipoidea. Das Tierreich 24: 1-891. Kieffer, J. 1907. Beschreibung neuer parasitischer Cynipiden aus Zentralund Nord Amerika. Entomologische Zeitschift 21: 70-91.

Kieffer, J. 1908. Nouveaux proctotrypides et cynipides d'Amérique recueillis par M. Baker chef de la Station agronomique de Cuba. Annales de la Société Scientifique de Bruxelles 32: 7-64. 